\title{
Linkages between gold and Latin American equity markets: portfolio implications
}

\author{
Imran Yousaf, Hasan Hanif and Shoaib Ali \\ Air University School of Management, Air University, Islamabad, Pakistan, and \\ Syed Moudud-Ul-Huq \\ Mawlana Bhashani Science and Technology University, Tangail, Bangladesh
}

Gold and Latin American equity markets

Received 17 April 2020 Revised 24 October 2020 2 July 2021

Accepted 8 July 2021

\begin{abstract}
Purpose - The authors aim to examine the mean and volatility linkages between the gold market and the Latin American equity markets in the entire sample period and two crises periods, namely the US financial crisis and the Chinese crash.

Design/methodology/approach - To examine the return and volatility spillovers, the authors employ VARBEKK-GARCH model on the daily data of four emerging Latin American equity markets which include Peru, Chile, Brazil and Mexico, which ranges from January 2000 to June 2018.

Findings - The results show that the return transmissions vary across the stock markets and the crises periods. The volatility transmission is found to be bidirectional between the gold and stock markets of Brazil and Chile during the US financial crisis. Furthermore, the volatility spillover is unidirectional from Brazil to gold and from gold to Peru stock market during the Chinese crash. We also calculate the optimal weights hedge ratios for gold and stock portfolio. The result suggests that portfolio managers need to increase the weight of gold for the equity portfolios of Peru and Mexico during the US financial crisis. Furthermore, during the Chinese crisis, investors may raise the investment in gold for the equity portfolios of Brazil and Chile. Finally, the cheapest hedging strategy is CHIL/GOLD during the US financial crisis, whereas MEXI/GOLD during the Chinese crash.

Practical implications - These findings have useful insights for portfolio diversification, asset pricing and risk management.

Originality/value - The study's outcome provides policymakers and investors with in-depth insights regarding hedging, risk management and portfolio management.
\end{abstract}

Keywords Gold markets, Equity markets, US financial crises, Chinese equity market crash

Paper type Research paper

\section{Introduction}

The stock markets are crucial in the optimal allocation and mobilization of financial resources to support economic activities (Carp, 2012). In the past, the stock markets were adversely affected by several financial crises (Bouri, 2015; Umar et al., 2021b), and investors suffered massive losses. Investors are always searching for alternate assets/safe haven that can diversify the risk of stocks portfolios during crises episodes. Gold is considered as the safehaven investment against the equities during the huge uncertainty phases of the markets (Baur and McDermott, 2010). Therefore, it is important to examine the gold-stock nexus during the crisis's episodes to provide valuable insights to the investors and portfolio

\section{JEL Classification - G10, G13}

(C) Imran Yousaf, Hasan Hanif, Shoaib Ali and Syed Moudud-Ul-Huq. Published in Journal of Economics, Finance and Administrative Science. Published by Emerald Publishing Limited. This article is published under the Creative Commons Attribution (CC BY 4.0) licence. Anyone may reproduce, distribute, translate and create derivative works of this article (for both commercial and non-commercial purposes), subject to full attribution to the original publication and authors. The full terms of this licence may be seen at http://creativecommons.org/licences/by/4.0/legalcode

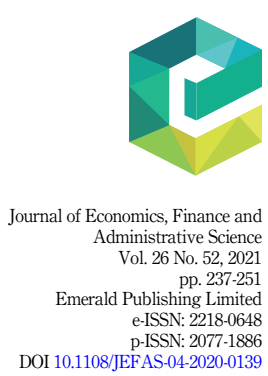


JEFAS

26,52

managers regarding diversification opportunities, hedging and portfolio allocation (Arouri et al., 2015).

Our research intends to investigate the mean and volatility links across gold assets and rising Latin American (LA) equity markets during various sample periods, including the fullsample period, the US financial crisis (UFC) and the Chinese equity market crash (CSMC). These linkages answer the important research question of whether gold can diversify the equity risk of LA equity markets during different sample periods. This study also computes the optimal portfolio-weights and hedge-ratios for gold and stock-based portfolios to provide information about optimal portfolio allocation, downside risk reduction and hedging during the crisis periods (Hammoudeh et al., 2014; Andreasson et al., 2016).

Several studies have explored the gold-stock nexus during the UFC (Arouri et al., 2015; Junttila et al., 2018; Yousaf et al., 2020a, 2021); however, studies are scant in the context of CSMC. The Chinese equity market crashed in 2015 (Han and Liang, 2017; Yousaf and Hassan, 2019), the CSI-300 index dropped 34\% in just 20 days at the start of the crisis. The Chinese equity market lost around $50 \%$ of the pre-crash market value and affected many emerging markets, including the emerging LA equity markets [1]. Trade and financial integration are directly associated with each other, and China is the major trading partner of LA economies, therefore the CSMC can influence the LA equity markets (Mata and Mora, 2016; Yousaf et al., 2020b).

The contribution of the current study is threefold. Firstly, as per our best understanding and published evidence, it is the first research that examines the return and volatility spillover between gold and LA equity markets during crisis periods, especially in the CSMC. However, literature provides the evidence of various studies that examines return/volatility transmission between world stock markets and gold (Badshah et al., 2013; Arouri et al., 2015; Gao and Zhang, 2016; Balcilar et al., 2018; Kang and Yoon, 2019; Jiang et al., 2019; Akkoc and Civcir, 2019; Adewuyi et al., 2019). Because none of the aforementioned research investigates the return/volatility relationships between gold and LA equity markets during the CSMC, therefore this study fills this literature gap.

Second, we estimate the spillovers employing the VAR-BEKK-GARCH model. This model is utilized in different studies for the analysis of return and volatility spillovers (Chen et al., 2020; Yu et al., 2020; Ahmed and Huo, 2021). Several studies also use the Wavelet approach and Diebold and Yilmaz approach for spillovers analysis (Umar et al., 2021a, c; Al-Yahyaee et al., 2019). The competitive models (i.e. DCC-GARCH and VAR-GARCH) suffer from convergence issues (Zhang and Choudhry, 2017; Yousaf and Ali, 2021). Moreover, the VARBEKK-GARCH model can estimate the conditional volatilities, covariances, time-varying correlation, which are utilized to compute hedge ratios using optimal weights. Finally, this research also augments the literature by providing the hedge ratios and optimal weights for the gold-stock pairs. The remainder of the paper is structured as follows: Section 2 describes the data and methodology. Section 3 provides the findings of this study. Finally, Section 4 concludes the whole research.

\section{Literature review}

A large amount of research has been conducted around the world to study the gold-stock nexus. Smith (2001) investigates the link between gold and the US equity market and reports a significant unidirectional causal impact from US equity returns to gold returns. Lawrence (2003) investigates the association between S\&P 500 index, gold and other commodities. He finds that gold returns are weakly associated with S\&P 500 returns as compared to the association between S\&P 500 and other commodities. Mishra et al. (2010) investigate the volatility of gold price and Indian equity market returns and confirm a 
bidirectional relationship. Choi and Hammoudeh (2010) empirically find that gold and S\&P 500 index have a very low correlation.

Miyazaki and Hamori (2013) study the links between the equity and gold markets. They find that unidirectional return spillover from equity to gold but report no evidence of volatility spillover between equity to the gold market. Before the crisis, bidirectional causality exists while unidirectional causality in mean and variance exists from equity to gold market after the crisis. In addition to that, Thuraisamy et al. (2013) examine the volatility spillover effect between fourteen Asian equity markets to the two commodities gold futures and crude oil markets. The study finds that spillover results of mature and immature markets are different from each other. In mature markets like Japan, volatility effects are transmitted to gold future and crude oil markets from the Japanese equity market. In comparison, the volatility effects are transferred from commodity futures to the equity markets in immature economies. Moreover, there is a presence of a bidirectional volatility transmission during the financial crisis.

During the global financial crisis, Arouri et al. (2015) discover a strong presence of return and volatility spillovers between gold and Chinese equity markets. While studying the relationship between gold and stock price of BRICS economies, Raza et al. (2016) confirm that the contribution of gold prices to the equity returns is positive. Furthermore, they argued that the relationship is negative for gold and equity markets of Malaysia, Chile, Thailand, Indonesia and Mexico. In line with the studies mentioned above, Bekiros et al. (2017) confirm the diversifier role of gold for BRICS stock markets.

Vardar et al. (2018) confirm that volatility is transmitted from developed and emerging equity markets to the gold market. Moreover, Shakil et al. (2018), through an autoregressive distributed lag model (ARDL), discovered that gold is useful as a portfolio hedge because it is not affected by the consumer price index. They found that external factors as the financial crisis may be harmful to the consumer price index. Thus, adding a percentage of gold to the investment portfolio may reduce the risk level. Using data from the Turkish equity market, Akkoc and Civcir (2019) discovered a significant unidirectional volatility transmission from gold and oil. Al-Yahyaee et al. (2019) find that the precious metals provide more diversification opportunities against the GCC stocks than the energy markets. While studying the Indian equity market, Maitra and Dawar (2019) report that the unidirectional return spillover from the commodity to the Indian equity market. Singhal et al. (2019) find that international gold prices have a substantial positive impact on Mexican equity prices.

Yamaka and Maneejuk (2020) find a stronger integration between gold and Asian stocks markets during the UFC than pre- and post-crisis. While examining the quantile connectedness between BRICS equity markets and gold, Naeem et al. (2020) confirm the diversifier role of gold against the BRICS equity markets. He et al. (2020) look at the linkages between gold and the US and the China equity markets and report that the US and Chinese equity markets are the net recipients of volatility effects from the gold market. Moreover, the gold market volatility positively (negatively) influences the volatility of the US (China).

Morema and Bonga-Bonga (2020) provide evidence of bidirectional volatility spillover between South African equity markets, gold and oil. Hung and Vo (2021) report the strong connectedness between oil, gold and equity markets during COVID-19 compared to the prepandemic period. Mensi et al. (2021) investigate the asymmetric spillovers between the oil, gold and Chinese equity market and find that the negative return spillover dominates the positive return spillovers. Moreover, the connectedness between these markets varies during UFC, oil-price crash and the pandemic period. According to the aforementioned literature, none of the studies have explored the return and volatility transmissions between the gold 
JEFAS

26,52

and LA equity markets during crises; consequently, this study substantially contributes to the current body of knowledge by filling up the gaps described above.

\section{Data and methodology}

\subsection{Data}

To examine the gold-stock nexus, this study uses daily data from January 2000 to June 2018. Following MSCI emerging market index, this study sample consisted of four emerging LA equity markets: Brazil, Mexico, Chile and Peru. The data is further divided into two subsamples (1) the UFC - which starts in August 2007 and ends in July 2010) and (2) the CSMC - which starts in June 2015 and ends in May 2018. The three-year span is used for each crisis, as used by Yousaf and Hassan (2019). On non-trading days, the index value is assumed to be the same as the previous trading day. The data pertaining to equity indices have been extracted from the Data Stream database. To examine spillover between gold and equity returns, the data of daily London gold spot prices (in the US dollars per troy ounce) has been taken from the London Bullion Market Association homepage (Santillán Salgado et al., 2018).

\subsection{Methodology}

To estimate return and volatility spillover through the VAR-BEKK-GARCH model, the empirical method consists of two parts. In the first part, we use vector autoregression (VAR) for the estimations of return spillovers. In the second part, we apply the BEKK-GARCH model to estimate volatility spillovers, suggested by Engle and Kroner (1995). For return spillovers, below are the specifications of the condition mean equation:

$$
R_{t}=\mu+\varnothing R_{t-1}+e_{t} \text { with } e_{t}=H_{t}^{1 / 2} \eta_{t} .
$$

$R_{t}=\left(R_{t}^{x}, R_{t}^{y}\right)^{\prime}$ is the vector of returns on the stock index $(S)$ and gold $(G)$ at time $t$, respectively. $\varnothing$ is the $2 \times 2$ matrix of parameters, which estimate the impact of own lagged and cross return spillovers between $S$ and $G$ series. $e_{t}=\left(e_{t}^{S}, e_{t}^{G}\right)^{\prime}$ is the vector of error terms of the mean equations for $S$ and $G$ series at time $t . \eta_{t}=\left(\eta_{t}^{S}, \eta_{t}^{G}\right)^{\prime}$ indicates a sequence of identically and independently distributed random errors. $H_{t}=\left(\begin{array}{cc}H_{t}^{S} & H_{t}^{S G} \\ H_{t}^{S G} & H_{t}^{G}\end{array}\right)$ indicates the variancecovariance matrix of the $\mathrm{S}$ and $\mathrm{G}$ return series. Besides, $H_{t}^{1 / 2}$ is the $2 \times 2$ symmetric positive definite matrix.

For volatility spillovers, the full BEKK-GARCH $(1,1)$ is employed, which requires positive definiteness restrictions for $H_{t}$, is given by:

$$
H_{t}=C^{\prime} C+A^{\prime} e_{t-1} e_{t-1}^{\prime} A+B^{\prime} H_{t-1} B
$$

here $C$ is a lower triangular matrix, whereas the $A, B$ and $D$ are the square-matrices, described as follows:

$$
C=\left(\begin{array}{cc}
c_{11} & 0 \\
c_{21} & c_{22}
\end{array}\right), A=\left(\begin{array}{ll}
a_{11} & a_{12} \\
a_{21} & a_{22}
\end{array}\right), B=\left(\begin{array}{ll}
b_{11} & b_{12} \\
b_{21} & b_{22}
\end{array}\right)
$$

In the above equation, the order of variables is the Stock (1) and Gold (2) for our analysis. The $\mathrm{ARCH}$ and GARCH effects are represented by the matrix $A$ and $B$, respectively. More specifically, $a_{12}$ means that the shock spillover from equity to gold market, and $b_{12}$ indicates the volatility transmission from the equity to the gold market. 
The output of the VAR-BEKK-GARCH model is used to compute the optimal portfolio weights and the subsequent hedge ratios. Consistent with the study of Kroner and Ng (1998) the optimal portfolio weight of stock $(S)$ and gold $(G)$ is computed as follows:

$$
\begin{array}{r}
w_{S G, t}=\frac{h_{G, t}-h_{S G, t}}{h_{S, t}-2 h_{S G, t}+h_{G, t}} \\
w_{S G, t}=\left\{\begin{array}{lll}
0, & \text { If } & W_{S G, t}<0 \\
w_{S G, t}, & \text { If } & 0 \leq w_{S G, t} \leq 1 \\
1, & \text { If } & w_{S G, t}>1
\end{array}\right.
\end{array}
$$

Gold and Latin American equity markets

Considering $\$ 1$ portfolio of stock and gold, $w_{S G, t}$ represents the weight of stock and $1-w_{S G, t}$ is the weight of gold. $h_{s g, t}$ represents the conditional covariance between equity and gold, $h_{s, t}$ and $h_{g, t}$ indicate the conditional variance of equity and gold, respectively. Following specifications are used to estimate hedge ratio, proposed by Kroner and Sultan (1993):

$$
\beta_{S G, t}=\frac{h_{S G, t}}{h_{G, t}}
$$

$\beta_{s g, t}$ denotes the hedge ratio. A long position in stock can be hedged with a short position in the gold assets.

\section{Results}

\subsection{Descriptive analysis}

Table 1 shows the full-sample descriptive statistics of gold and equity indices. The complete sample period results reveal that the mean return of the Peru (Mexico) equity market is the highest (lowest). The standard deviation of returns is the highest (lowest) for Brazil (Chile) equity market. The Chile and Peru equity markets provide reasonable returns with comparatively lower risks. Furthermore, the outcome also discloses that the Skewness of all indices is negative, and kurtosis is above 3 . Based on Jarque-Bera statistics, the normality hypothesis cannot be rejected for all series. Moreover, the finding provides evidence of the presence of autocorrelation for all series. Lastly, all series exhibit strong evidence of the ARCH effect; therefore, we can apply GARCH models. To ascertain the stationarity of the series, the Augmented Dickey-Fuller (ADF) test and Phillip-Perron test are applied, and results of the unit root test are reported in Table 2. Each test is applied three times, with "no constant and trend", "constant" and "constant and trend". The findings depict that all series are significant while applying ADF and Phillip-Perron test; thus, there is no evidence of stationarity in any series.

\subsection{Results of spillover b/w gold assets and Latin American equity markets}

4.2.1 Full-sample results. Table 3 shows the results of the spillovers between gold and LA equity markets. The lagged returns are significant in Chile, Mexico and Peru equity markets, implying that the historical returns help determine the current returns in these three markets. As far as the gold market is concerned, past returns do not influence the current returns. The outcome reveals unidirectional return spillover from Brazil, Chile and Peru equity markets to the gold market.

Refer to the variance equation, the lagged shocks and volatility have a significant influence on the recent conditional volatility, and results are consistent across all indices. The impact of the series own past volatility is higher than that of series own past shocks in equity markets of LA, suggesting that past volatility is a more important predictor of the current 
JEFAS

26,52

242

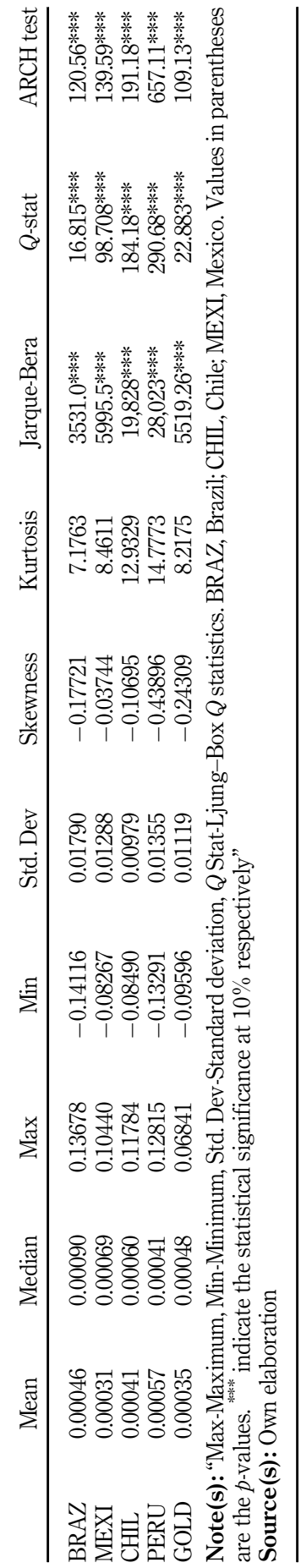

Table 1.
Summary statistics 


\begin{tabular}{|c|c|c|c|c|c|c|c|}
\hline & & $\mathrm{ADF}$ & & & PP-t & & $n$ \\
\hline & None & Constant & Constant and trend & None & Constant & Constant and trend & erica \\
\hline BRAZ & -66.352 & -66.39 & -66.388 & -66.287 & -66.3303 & -66.328 & \\
\hline MEXI & -47.81 & -47.844 & -47.84 & -60.31 & -60.3353 & -60.329 & \\
\hline CHIL & -57.259 & -57.34 & -57.336 & -56.931 & -56.9878 & -56.982 & \\
\hline PERU & -29.73 & -29.818 & -29.833 & -57.468 & -57.2741 & -57.259 & \\
\hline GOLD & -66.741 & -66.801 & -66.811 & -66.743 & -66.8028 & -66.8142 & 243 \\
\hline Note(s & “ADF-Aug & ented Dicke & -Fuller test. PP test-Phi & ps-Perron & t. BRAZ, Br & il; CHIL, Chile; MEXI, & \\
\hline $\begin{array}{l}\text { Mexico } \\
\text { Source }\end{array}$ & ): Own ela & & & & & & $\begin{array}{l}\text { Tal } \\
\text { Unit roo }\end{array}$ \\
\hline
\end{tabular}

volatility in equity markets. Furthermore, the past own shocks and volatility of gold have a significant impact on its conditional volatility. In addition to that, the lagged shocks of the gold market significantly and negatively affect all equity markets. Interestingly, the past shocks of the Mexican equity market also influence the volatility of gold markets. It proposes that the past shocks of Mexico are important in forecasting the gold market.

The results confirm unidirectional volatility spillover from the gold to Chile, Brazil and Mexico stock markets, suggesting that the gold market volatility is useful in forecasting the volatility of Brazil, Chile and Mexico equity markets. However, the bidirectional volatility transmission is observed between gold and the Peru equity markets, proposing that both markets are highly connected, and their portfolio provides no diversification.

4.2.2 US financial crisis period results. For the sample period of UFC, the results of returns and volatility linkages are reported in Table 4. The past returns of Chile and Peru significantly influence their current returns, showing the forecasting power of Chile and Peru's past returns. In contrast, the lagged gold returns do not affect the current gold returns. The result reports unidirectional return spillover from the Brazil and Peru equity markets to the gold market, suggesting that these equity markets are useful in forecasting the gold market.

The lagged volatility(shocks) has a (in)significant effect on the contemporaneous volatility in the equity markets, and the findings are consistent across all equity indices, suggesting that the past volatility of LA equity markets is an important determinant of their current volatility. In contrast, the current volatility of gold is significantly influenced by its lagged shocks and volatility, suggesting that past shocks and volatility are significant in determining the current volatility of the gold market during the UFC.

The results indicate bidirectional volatility transmission between equity markets of Brazil and Chile and the gold, therefore highlighting that the portfolios of gold and these two equity markets provide no opportunities for diversifications. However, the volatility linkages are not significant between the gold and equity markets of Mexico and Peru. The findings outline that the maximum benefits of diversification can be derived by adding gold in the undiversified portfolios of Mexico and Peru during the UFC.

4.2.3 Chinese equity market crash results. Table 5 displays the results of return and volatility linkages between gold and LA equity markets in the CSMC. Their past returns have a significant influence on the current returns of Peru, Chile and Mexico equity markets. In contrast, the lagged gold returns are not significant, indicating that past returns of gold are not useful in forecasting current gold returns. The cross-market return spillover is unidirectional only from gold to the Mexican equity market, suggesting that returns of the Mexican equity market can be predicted using the gold market during the CSMC.

Refers to the variance equation, past shocks and volatility have a significant effect on the current volatility in all the equity markets. Additionally, current conditional volatility is also 
JEFAS

26,52

\section{4}

Table 3.

Estimates of bivariate VAR-BEKK-GARCH for gold assets and Latin American markets during fullsample period

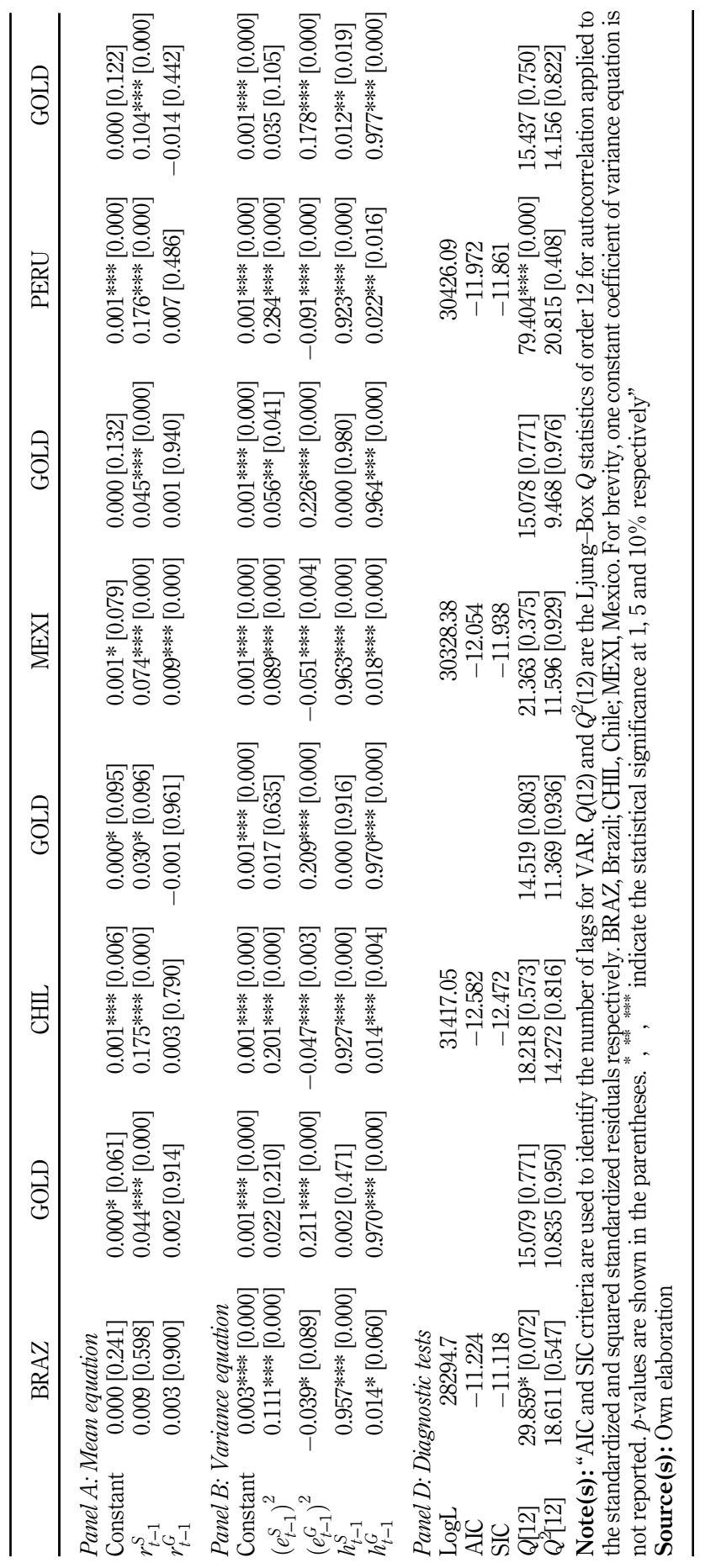




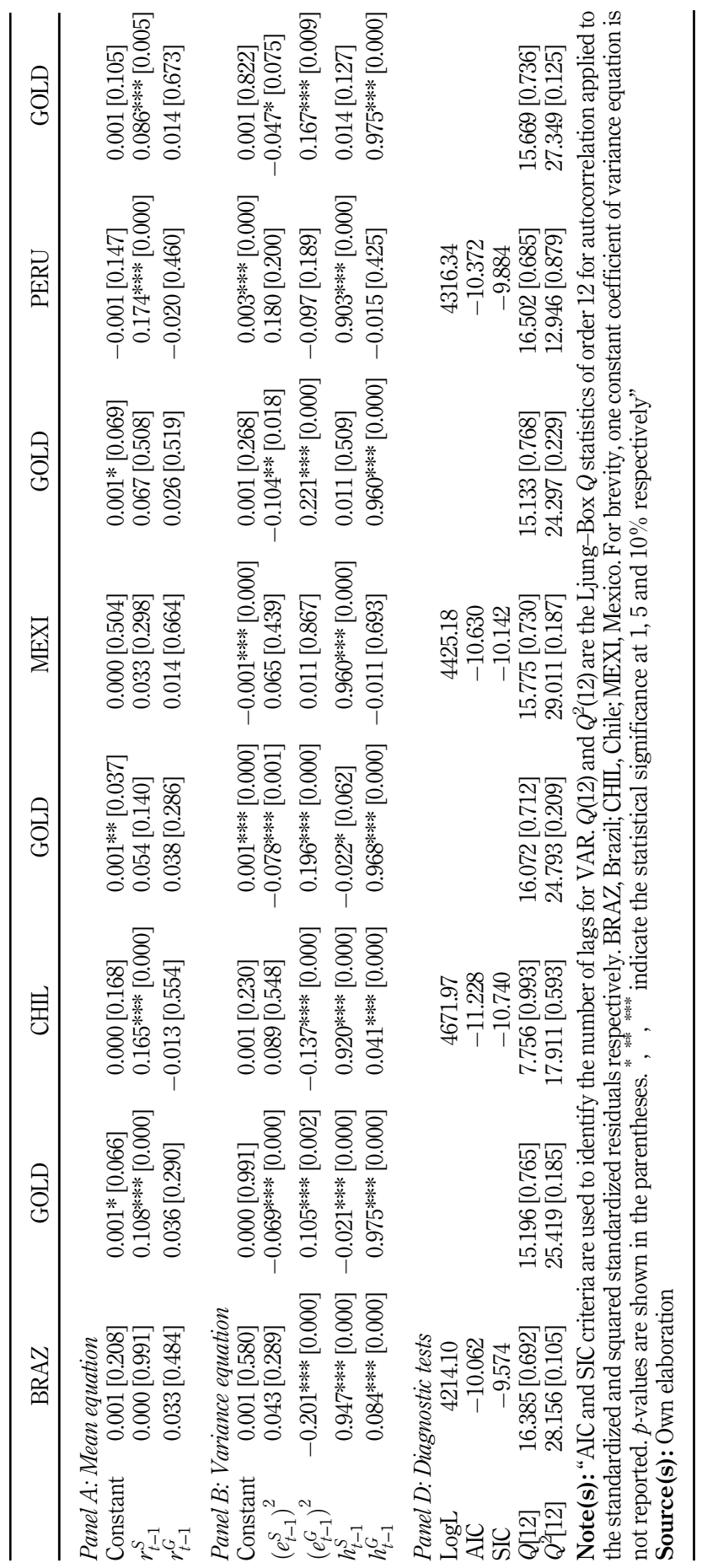

Gold and Latin American equity markets

245

Table 4. Estimates of bivariate VAR-BEKK-GARCH for gold assets and Latin American equity markets during US financial crisis 
JEFAS

26,52

\section{6}

Table 5.

Estimates of bivariate VAR-BEKK-GARCH for gold assets and Latin American equity markets during Chinese equity market crash

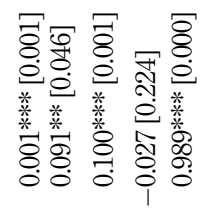

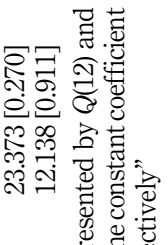

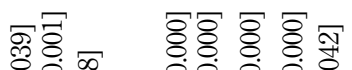

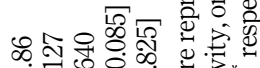

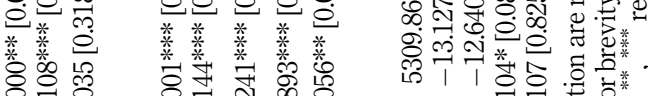

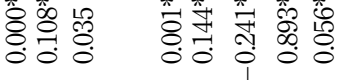

Sิ 合

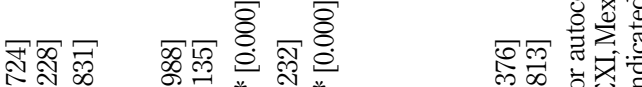
N.

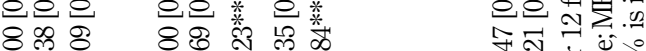
ठ융 ठ융 औै \% :

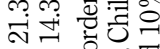
पै붕

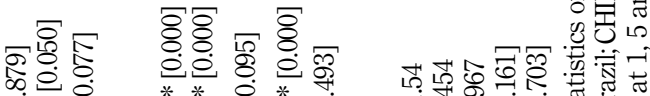

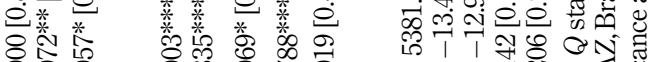

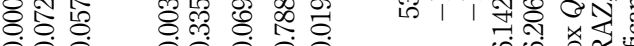

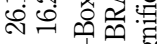

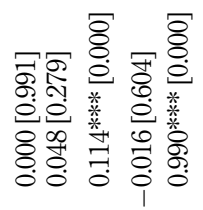

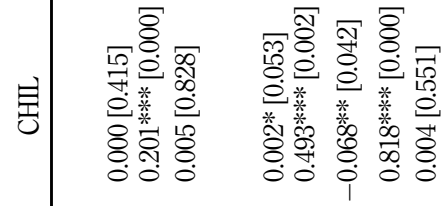

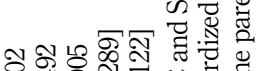

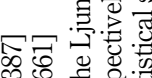
○远记 8 앙. 면

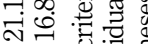
on

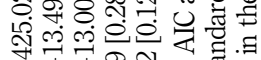

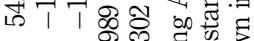
ลें

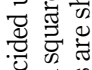

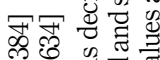

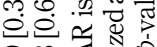
尺े क्ष

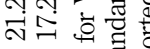

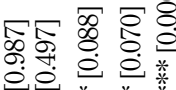

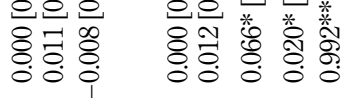
点芯运

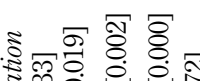
년

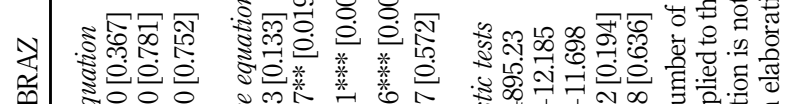

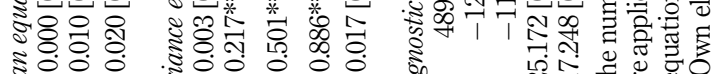

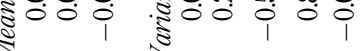

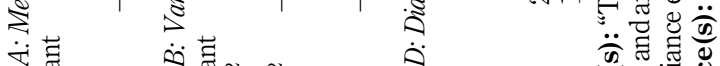

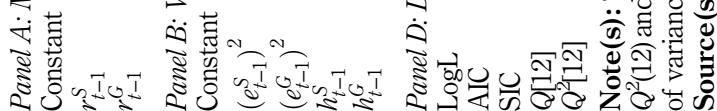


influenced by past volatility and shock in the gold market. The findings of the research signify the important role of past volatility as the determinant of current volatility during the CSMC. The cross-market shock spillover is unidirectional from the gold to Brazil, Chile and Mexico equity markets, whereas bidirectional between the gold and Peru equity market during the CSMC. The cross-market volatility spillover is unidirectional from Brazil to gold, and gold to Peru during the CSMC. Moreover, the volatility linkages are not significant between the gold and equity markets of Chile and Mexico, therefore investors are suggested to add gold in their equity portfolios of Chile and Mexico during the CSMC in order to obtain maximum benefits of diversification.

\subsection{Optimal weights and hedge ratios}

Hedge ratios and optimal weights across all pairs are reported in Table 6. In the full-sample period, for BRAZ/GOLD(CHIL/GOLD) pair, the optimal weight is $0.29(0.59)$, indicating that, for a $\$ 1$ portfolio, investors should invest 29(59) cents in the Brazilian (Chile) equity market and the remaining amount in gold. For the pairs of MEXI/GOLD and PERU/GOLD, it is suggested to allocate 48 cents in the Mexico and Peru equity markets and the remaining 52 cents in the gold market during the full-sample period.

The optimal weights for BRAZ/GOLD and CHIL/GOLD pairs are higher during the UFC than CSMC. For the gold-stock portfolio, it is suggested that investors decrease (increase) the weight of gold for the equity portfolios of Brazil and Chile during the UFC (the CSMC). In contrast, the optimal weights are higher for the MEXI/GOLD and PERU/GOLD pairs during the CSMC compared to the UFC, proposing that, for the portfolio of gold-stock, the portfolio managers increase (decrease) the weight of gold during the UFC (the CSMC).

For the full-sample, the hedge ratio is 0.06 for the BRAZ/GOLD pair, suggesting that a $\$ 1$ long position in Brazilian stocks can be hedged with the short position of 6 cents in the gold during the full-sample period. During the full-sample period and the UFC, the lowest hedging ratio is observed in the pair of CHIL/GOLD, therefore the cheapest hedging strategy is the $\mathrm{CHIL} / \mathrm{GOLD}$. However, the highest hedging ratio is reported for the PERU/GOLD pair, therefore the expensive hedging strategy is the PERU/GOLD during the full-sample period and the UFC. In contrast, during the CSMC, the cheapest hedging strategy is the MEXI/GOLD and the expensive hedging strategy is the PERU/GOLD. Overall, these optimal weights and hedge ratios vary across the sample periods, requiring investors to adjust their portfolio allocation and hedging strategy, specifically during the crisis period to get maximum benefits from their portfolios of gold and LA equity markets.

\begin{tabular}{|c|c|c|c|c|c|}
\hline & BRAZ/GOLD & $\mathrm{CHIL} / \mathrm{GOLD}$ & MEXI/GOLD & PERU/GOLD & \\
\hline \multicolumn{6}{|c|}{ Full-sample period } \\
\hline$w_{t}^{S G}$ & 0.29 & 0.59 & 0.48 & 0.48 & \\
\hline$\beta_{t}^{S G}$ & 0.06 & 0.01 & 0.02 & 0.15 & \\
\hline \multicolumn{6}{|c|}{ US financial crisis } \\
\hline$w_{t}^{S G}$ & 0.32 & 0.63 & 0.46 & 0.40 & \\
\hline$\beta_{t}^{S G}$ & 0.10 & 0.00 & 0.11 & 0.14 & \\
\hline \multicolumn{6}{|c|}{ Chinese equity market crash } \\
\hline$w_{t}^{S G}$ & 0.25 & 0.56 & 0.53 & 0.49 & Table 6. \\
\hline$\beta_{t}^{S G}$ & 0.08 & 0.02 & -0.05 & 0.11 & Optimal weights and \\
\hline \multicolumn{5}{|c|}{$\begin{array}{l}\text { Note(s): } w_{t}^{S G} \text { and } \beta_{t}^{S G} \text { indicates the optimal weights and optimal hedge ratios respectively } \\
\text { Source(s): Own elaboration }\end{array}$} & $\begin{array}{l}\text { Latin American equity } \\
\text { markets and gold }\end{array}$ \\
\hline
\end{tabular}


JEFAS

26,52

248

\section{Discussion and conclusions}

The current study attempts to analyze the mean and volatility linkages across the gold market and the LA equity markets. Apart from full-sample analysis, we further split the data into two different subsamples: the CSMC and the UFC. The optimal portfolio weights and hedge ratios are also computed for the gold market and stock markets.

The results show that the return spillovers for gold-stock pairs vary across stock markets and crisis periods. The cross-market volatility transmission is unidirectional from Brazil, Chile and Mexico to the gold market, whereas bidirectional between the gold and Peru stock market during the full-sample period. During the UFC, the volatility transmission is bidirectional between the gold and stock markets of Brazil and Chile, suggesting that the portfolios of gold and these two equity markets provide no opportunities for diversifications. However, the volatility linkages are not significant between the gold and equity markets of Mexico and Peru, suggesting the addition of add gold in the undiversified portfolios of Mexico and Peru stocks to get the maximum benefit of diversification during the UFC. During the Chinese crash, the volatility spillover is unidirectional from Brazil to gold, and gold to Peru, whereas the volatility spillovers are not significant between gold and stock markets of Chile and Mexico, suggesting that investors can diversify their portfolio of Chile and Mexico stocks by adding gold during the Chinese crash.

Overall, the optimal weights suggest that, for the gold and LA equity-based portfolios, investors must allocate at least one-third of their investment in gold, irrespective of any sample period. Based on optimal weights, it is suggested that investors should decrease (increase) their investment in gold for the equity portfolios of Brazil and Chile during the UFC (the Chinese crash). For the portfolio of gold stock, the portfolio managers should increase (decrease) their investment in the gold for the equity portfolios of Peru and Mexico during the UFC (the Chinese crash). Refers to the hedging ratios, the cheapest hedging strategy is CHIL/ GOLD during the full-sample period and the UFC. In contrast, the cheapest hedging strategy is MEXI/GOLD during the Chinese crash.

Based on spillovers results, we provide valuable information to portfolio managers and investors regarding the diversification opportunities. Moreover, the optimal weights suggest the portfolio allocation to investors and portfolio managers. We inform the investors about the cheapest hedging strategies during the different financial crises. Finally, the significant spillover from gold to the stock market provides useful information to policymakers regarding formulating policies in such a way that can make the local market resilient to shock from the outside (gold) markets. Overall, these findings provide useful insights to portfolio managers, investors and policymakers regarding portfolio diversification, asset allocation, asset pricing, hedging and risk management, especially during a crisis.

For future studies, we suggest the investigation of the spillover between the gold and the Latin American Integrated Market (MILA), relevant stock market studied due to the Pacific Alliance (Vergara Garavito and Chion, 2021). Moreover, these spillovers between gold and MILA, due to the Pacific Alliance development can be compared with the spillover between gold and Brazil. Apart from this, our study just focuses on the UFC and the CSMC, therefore it is also suggested to examine these spillovers during the COVID-19 pandemic.

\section{Note}

1. https://money.cnn.com/2015/07/09/news/economy/warning-sign-latin-america-economy/index.html

\section{References}

Adewuyi, A.O., Awodumi, O.B. and Abodunde, T.T. (2019), "Analysing the gold-stock nexus using VARMA-BEKK-AGARCH and Quantile regression models: new evidence from South Africa and Nigeria”, Resources Policy, Vol. 61, pp. 348-362. 
Ahmed, A.D. and Huo, R. (2021), "Volatility transmissions across international oil market, commodity futures and stock markets: empirical evidence from China”, Energy Economics, Vol. 93, p. 104741.

Akkoc, U. and Civcir, I. (2019), "Dynamic linkages between strategic commodities and stock market in

Gold and Latin American equity markets Turkey: evidence from SVAR-DCC-GARCH model”, Resources Policy, Vol. 62, pp. 231-239.

Al-Yahyaee, K.H., Mensi, W., Sensoy, A. and Kang, S.H. (2019), "Energy, precious metals, and GCC stock markets: is there any risk spillover?”, Pacific-Basin Finance Journal, Vol. 56, pp. 45-70.

Andreasson, P., Bekiros, S., Nguyen, D.K. and Uddin, G.S. (2016), "Impact of speculation and economic uncertainty on commodity markets", International Review of Financial Analysis, Vol. 43, pp. 115-127.

Arouri, M.E.H., Lahiani, A. and Nguyen, D.K. (2015), "World gold prices and stock returns in China: insights for hedging and diversification strategies", Economic Modelling, Vol. 44, pp. 273-282.

Badshah, I.U., Frijns, B. and Tourani-Rad, A. (2013), "Contemporaneous spillover among equity, gold, and exchange rate Implied Volatility Indices”, Journal of Futures Markets, Vol. 33 No. 6, pp. 555-572.

Balcilar, M., Ozdemir, Z.A. and Ozdemir, H. (2018), "Dynamic return and volatility spillovers among S\&P 500, crude oil, and gold", International Journal of Finance and Economics. doi: 10.1002/ ijfe.1782.

Baur, D.G. and McDermott, T.K. (2010), "Is gold a safe-haven? International evidence", Journal of Banking and Finance, Vol. 34 No. 8, pp. 1886-1898.

Bekiros, S., Boubaker, S., Nguyen, D.K. and Uddin, G.S. (2017), "Black swan events and safe-havens: the role of gold in globally integrated emerging markets", Journal of International Money and Finance, Vol. 73, pp. 317-334.

Bouri, E. (2015), "Return and volatility linkages between oil prices and the Lebanese stock market in crisis periods”, Energy, Vol. 89, pp. 365-371.

Carp, L. (2012), "Can stock market development boost economic growth? Empirical evidence from emerging markets in Central and Eastern Europe", Procedia Economics and Finance, Vol. 3, pp. 438-444.

Chen, Y., Zheng, B. and Qu, F. (2020), "Modeling the nexus of crude oil, new energy and rare earth in China: an asymmetric VAR-BEKK (DCC)-GARCH approach”, Resources Policy, Vol. 65, p. 101545.

Choi, K. and Hammoudeh, S. (2010), "Volatility behavior of oil, industrial commodity and stock markets in a regime-switching environment", Energy Policy, Vol. 38 No. 8, pp. 4388-4399.

Engle, R.F. and Kroner, K.F. (1995), "Multivariate simultaneous generalized ARCH", Econometric Theory, pp. 122-150.

Gao, R. and Zhang, B. (2016), "How does economic policy uncertainty drive gold-stock correlations? Evidence from the UK", Applied Economics, Vol. 48 No. 33, pp. 3081-3087.

Hammoudeh, S., Nguyen, D.K., Reboredo, J.C. and Wen, X. (2014), "Dependence of stock and commodity futures markets in China: implications for portfolio investment", Emerging Markets Review, Vol. 21, pp. 183-200.

Han, Q. and Liang, J. (2017), "Index futures trading restrictions and spot market quality: evidence from the recent Chinese equity market crash", Journal of Futures Markets, Vol. 37 No. 4, pp. 411-428.

He, X., Takiguchi, T., Nakajima, T. and Hamori, S. (2020), "Spillover effects between energies, gold, and stock: the United States versus China", Energy and Environment, Vol. 31 No. 8, pp. 1416-1447.

Hung, N.T. and Vo, X.V. (2021), "Directional spillover effects and time-frequency nexus between oil, gold and stock markets: evidence from pre and during COVID-19 outbreak", International Review of Financial Analysis, Vol. 76, p. 101730.

Jiang, Y., Fu, Y. and Ruan, W. (2019), "Risk spillovers and portfolio management between precious metal and BRICS stock markets", Physica A: Statistical Mechanics and Its Applications, Vol. 534, p. 120993. 
JEFAS

26,52

Junttila, J., Pesonen, J. and Raatikainen, J. (2018), “Commodity market based hedging against stock market risk in times of financial crisis: the case of crude oil and gold", Journal of International Financial Markets, Institutions and Money, Vol. 56, pp. 255-280.

Kang, S.H. and Yoon, S.M. (2019), "Financial crises and dynamic spillovers among Chinese equity and commodity futures markets", Physica A: Statistical Mechanics and Its Applications, Vol. 531, p. 121776.

Kroner, K.F. and Ng, V.K. (1998), "Modeling asymmetric comovements of asset returns", The Review of Financial Studies, Vol. 11 No. 4, pp. 817-844.

Kroner, K.F. and Sultan, J. (1993), "Time-varying distributions and dynamic hedging with foreign currency futures", Journal of Financial and Quantitative Analysis, Vol. 28 No. 4, pp. 535-551.

Lawrence, C. (2003), Why Is Gold Different from Other Assets? an Empirical Investigation, World Gold Council, London.

Maitra, D. and Dawar, V. (2019), "Return and volatility spillover among commodity futures, stock market and exchange rate: evidence from India”, Global Business Review, Vol. 20 No. 1, pp. 214-237.

Mata, L. and Mora, J.A.N. (2016), "Dependence between the Chinese and MILA equity markets", Journal of Chinese Economic and Foreign Trade Studies, Vol. 9 No. 3.

Mensi, W., Al Rababa'a, A.R., Vo, X.V. and Kang, S.H. (2021), “Asymmetric spillover and network connectedness between crude oil, gold, and Chinese sector stock markets", Energy Economics, Vol. 98, p. 105262.

Mishra, P.K., Das, J.R. and Mishra, S.K. (2010), "Gold price volatility and stock market returns in India”, American Journal of Scientific Research, Vol. 9 No. 9, pp. 47-55.

Miyazaki, T. and Hamori, S. (2013), "Testing for causality between the gold return and stock market performance: evidence for 'gold investment in case of emergency", Applied Financial Economics, Vol. 23 No. 1, pp. 27-40.

Morema, K. and Bonga-Bonga, L. (2020), "The impact of oil and gold price fluctuations on the South African equity market: volatility spillovers and financial policy implications", Resources Policy, Vol. 68, p. 101740.

Naeem, M.A., Hasan, M., Arif, M., Balli, F. and Shahzad, S.J.H. (2020), "Time and frequency domain quantile coherence of emerging stock markets with gold and oil prices", Physica A: Statistical Mechanics and Its Applications, Vol. 553, p. 124235.

Raza, N., Shahzad, S.J.H., Tiwari, A.K. and Shahbaz, M. (2016), "Asymmetric impact of gold, oil prices and their volatilities on stock prices of emerging markets", Resources Policy, Vol. 49, pp. 290-301.

Santillán Salgado, R.J., Fonseca Ramírez, A. and Venegas Martínez, F. (2018), “The impact of metals' prices on the capital structure of mining and metallurgic firms in Latin America (2004-2014)", Contaduría Y Administración, Vol. 63 No. 3, pp. 1-10.

Shakil, M.H., Mustapha, I.M., Tasnia, M. and Saiti, B. (2018), "Is gold a hedge or a safe haven? An application of ARDL approach", Journal of Economics, Finance and Administrative Science, Vol. 23 No. 44, pp. 60-76, doi: 10.1108/JEFAS-03-2017-0052.

Singhal, S., Choudhary, S. and Biswal, P.C. (2019), "Return and volatility linkages among international crude oil price, gold price, exchange rate and stock markets: evidence from Mexico", Resources Policy, Vol. 60, pp. 255-261.

Smith, G. (2001), "The price of gold and stock price indices for the United States", The World Gold Council, Vol. 8 No. 1, pp. 1-16.

Thuraisamy, K.S., Sharma, S.S. and Ahmed, H.J.A. (2013), "The relationship between Asian equity and commodity futures markets", Journal of Asian Economics, Vol. 28, pp. 67-75.

Umar, Z., Gubareva, M., Yousaf, I. and Ali, S. (2021a), "A tale of company fundamentals vs sentiment driven pricing: the case of GameStop", Journal of Behavioral and Experimental Finance, Vol. 30, p. 100501. 
Umar, Z., Yousaf, I. and Aharon, D.Y. (2021b), "The relationship between yield curve components and equity sectorial indices: evidence from China”, Pacific-Basin Finance Journal, Vol. 68, p. 101591.

Umar, Z., Yousaf, I. and Zaremba, A. (2021c), "Comovements between heavily shorted stocks during a market squeeze: lessons from the GameStop trading frenzy", Research in International Business and Finance, Vol. 58, p. 101453, doi: 10.1016/j.ribaf.2021.101453.

Vardar, G., Coşkun, Y. and Yelkenci, T. (2018), "Shock transmission and volatility spillover in stock and commodity markets: evidence from advanced and emerging markets", Eurasian Economic Review, Vol. 8 No. 2, pp. 231-288.

Vergara Garavito, J. and Chión, S.J. (2021), "Relationship between cash holdings and expected equity returns: evidence from Pacific Alliance countries", Journal of Economics, Finance and Administrative Science, Vol. 26 No. 51, pp. 77-93, doi: 10.1108/JEFAS-03-2020-0078.

Yamaka, W. and Maneejuk, P. (2020), "Analyzing the causality and dependence between gold shocks and Asian emerging stock markets: a smooth transition copula approach", Mathematics, Vol. 8 No. 1, p. 120.

Yousaf, I. and Ali, S. (2021), "Linkages between stock and cryptocurrency markets during the COVID19 outbreak: an intraday analysis", Singapore Economic Review. doi: 10.1142/ S0217590821470019.

Yousaf, I. and Hassan, A. (2019), "Linkages between crude oil and emerging Asian stock markets: new evidence from the Chinese equity market crash", Finance Research Letters, Vol. 31, pp. 207-217.

Yousaf, I., Ali, S. and Wong, W.K. (2020a), "Return and volatility transmissions between metals and stocks: a study of the emerging Asian markets by using the VAR-AGARCH approach", AsiaPacific Journal of Operational Research, p. 2040020.

Yousaf, I., Ali, S. and Wong, W.K. (2020b), "Return and volatility transmission between world-leading and Latin American equity markets: portfolio implications", Journal of Risk and Financial Management, Vol. 13 No. 7, p. 148.

Yousaf, I., Ali, S. and Abbas, F. (2021), "Spillovers and portfolio risk management of gold and stock markets: evidence from emerging stock markets", Macroeconomics and Finance in Emerging Market Economies, pp. 1-17. doi: 10.1080/17520843.2021.1875628.

Yu, L., Zha, R., Stafylas, D., He, K. and Liu, J. (2020), "Dependences and volatility spillovers between the oil and stock markets: new evidence from the copula and VAR-BEKK-GARCH models", International Review of Financial Analysis, Vol. 68, p. 101280.

Zhang, Y. and Choudhry, T. (2017), "Forecasting the daily time-varying beta of European banks during the crisis period: comparison between GARCH models and the Kalman Filter", Journal of Forecasting, Vol. 36 No. 8, pp. 956-973.

\section{Further reading}

Mendoza, J.A.M., Yelpo, S.M.S., Ramos, C.L.V. and Fuentealba, C.L.D. (2020), "Effects of MILA on their stock markets: an empirical analysis on market activity and dynamic correlations", International Journal of Emerging Markets. doi: 10.1108/IJOEM-12-2019-1070.

\section{Corresponding author}

Imran Yousaf can be contacted at: imranyousaf.fin@gmail.com

For instructions on how to order reprints of this article, please visit our website:

www.emeraldgrouppublishing.com/licensing/reprints.htm

Or contact us for further details: permissions@emeraldinsight.com 